NBER WORKING PAPER SERIES

INNOVATION AND PRODUCTIVITY

Bronwyn H. Hall

Working Paper 17178

http://www.nber.org/papers/w17178

\author{
NATIONAL BUREAU OF ECONOMIC RESEARCH \\ 1050 Massachusetts Avenue \\ Cambridge, MA 02138 \\ June 2011
}

University of Maastricht and University of California at Berkeley. Email: bhhall@econ.berkeley.edu Paper prepared for the Nordic economic policy conference on productivity and competitiveness, 29 April 2011, Helsinki, Finland. The revision of this paper has benefitted greatly from comments by Ari Hytinnen, Jakob Madsden, Jacques Mairesse, and Anders Sorenson. I also thank John Jankowski for essential help with the US innovation data. This paper was produced as part of the SCIFI-GLOW Collaborative Project supported by the European Commission's Seventh Framework Programme for Research and Technological Development, under the Socio-economic Sciences and Humanities theme (Contract no. SSH7-CT-2008-217436). The views expressed herein are those of the author and do not necessarily reflect the views of the National Bureau of Economic Research.

NBER working papers are circulated for discussion and comment purposes. They have not been peerreviewed or been subject to the review by the NBER Board of Directors that accompanies official NBER publications.

(C) 2011 by Bronwyn H. Hall. All rights reserved. Short sections of text, not to exceed two paragraphs, may be quoted without explicit permission provided that full credit, including $\odot$ notice, is given to the source. 
Innovation and Productivity

Bronwyn H. Hall

NBER Working Paper No. 17178

June 2011, Revised August 2011

JEL No. O30

\section{ABSTRACT}

What do we know about the relationship between innovation and productivity among firms? The workhorse model of this relationship is presented and the implications of analysis using this model and the usually available data on product and process innovation are derived. The recent empirical evidence on the relationship between innovation and productivity in firms is then surveyed. The conclusion is that there are substantial positive impacts of product innovation on revenue productivity, but that the impact of process innovation is more ambiguous, suggesting some market power on the part of the firms being analyzed.

Bronwyn H. Hall

Dept. of Economics

549 Evans Hall

UC Berkeley

Berkeley, CA 94720-3880

and NBER

bhhall@nber.org 


\title{
Innovation and Productivity
}

\author{
Bronwyn H. Hall ${ }^{1}$ \\ July 2011
}

Early work on the sources of productivity growth revealed that growth in capital and labor explained less than half of such growth in the United States and many other countries. The remainder (the 'residual') was ascribed to technical change and a large literature grew up that attempted to find measures for technical change (improvements in capital and labor quality, R\&D activities, and so forth) and use these measures to try to explain the residual growth in productivity (Griliches 1996, 1998, among others). Considerable success has been achieved by this approach, to the extent that many countries are now moving to incorporate measures of R\&D capital stock in their systems of national income accounts, and therefore to directly attribute some of economic growth to its contribution as well as adding the creation of knowledge capital to output itself.

Driven by interest in the unexplained portion of productivity growth and partly in response to various economic slowdowns and productivity gaps among nations, a large body of research on innovative activity and productivity in firms has accumulated. For reasons of data availability, this work has mostly used two measures of innovative activity: R\&D spending and patent counts. ${ }^{2}$ As measures of innovation, each of these has both positive and negative attributes. Both pertain primarily to technological innovation and are more suited to measuring innovation in manufacturing firms than in other areas such as services. $R \& D$ spending has the advantage that it is denominated in comparable units (currency) and represents a (costly) decision variable on the part of the firm about its appropriate level of innovative activity. For the same reason, it is only an input to innovation and cannot tell us about innovation success. Patent counts are a measure of invention success, and can be considered at least a partial measure of innovation output, but they are inherently very noisy (a few are associated with very valuable inventions and most describe inventions of little value) and the extent of their innovation coverage varies by sector, with sectors like pharmaceuticals and instruments making heavy use of patents while other sectors use them very little.

As the industrial structure of advanced economies has shifted away from manufacturing and towards services, economists and others have gradually become aware that concepts

\footnotetext{
1 University of Maastricht, University of California at Berkeley, NBER, and IFS. Email:

bhhall@econ.berkeley.edu
}

${ }^{2} \mathrm{~A}$ recent survey of results for the R\&D-productivity relationship is Hall, Mairesse, and Mohnen (2010). 
like "technical change" and "R\&D" describe only some of the sources of increased productivity in the economy, and recent research has begun to look at innovation more broadly as a source of growth. This research has been greatly helped by the introduction of the Oslo Manual (Tanaka et al. 2005) with guidelines for the definition of various kinds of innovation and by the surveys of innovative activity in business firms that have been conducted in a large number of countries around the world, mostly using this manual as a guide (Mairesse and Mohnen 2010). Several non-R\&D kinds of innovative expenditure have been identified: the later phases of development and testing that are not included in R\&D, capital expenditures related to the introduction of new processes, marketing expenditures related to new products, certain kinds of employee training, expenditures on design and technical specifications, etc.

Figure 1, which is based on data from these kinds of surveys, shows the distribution of the share of firms that report any kind of innovation during the three year period 2006-2008 by country and size of firm. ${ }^{3}$ The figure is instructive: it shows that in most countries, between 30 and 50 per cent of firms introduce a product or process innovation during a three year period, and that the rate of introduction is much higher and also more even across countries among large firms, as might have been expected. In fact, the coefficient of variation for the innovation share across countries is 0.3 for the SMEs and 0.12 for the large firms, confirming the higher dispersion rate for SMEs.

Figure 2 shows a breakdown by product and process innovation, where innovation is defined as the development of a new to the firm process or product by the enterprise or its group. ${ }^{4}$ In this case we are able to compare the European countries to the United States, by restricting the population of firms to a common set of innovative sectors across the two regions. ${ }^{5}$ The two types of innovation are roughly equal, with a slight preference for process innovation and some differences across countries. It is however, worth noting that

\footnotetext{
${ }^{3}$ The data for this and the subsequent figure comes for the most part from the European Community Innovation Survey Data for the United States comes from the new 2008 Business R\&D and Innovation Survey (BRDIS), conducted by the National Science Foundation and may not be exactly comparable to the European data.

${ }^{4}$ In the US case, the definition does not include the group to which the enterprise belongs. Because group structures are rare in the US, this distinction makes little difference. However, it does mean that the European numbers could be slightly higher given the broader definition of the firm doing the innovating.

5 These sectors are manufacturing, telecommunications, computer services and software publishing, finance, and some technical professional services. The restriction is necessary because the U.S. data do not contain enough detail outside manufacturing to match the innovative sector definition used by Eurostat, which is quite broad. The narrow definition used here is NACE activities C, J58, J61, J62, J63, K, M71. The broader definition used by Eurostat and elsewhere in this paper includes NACE activities B, D, E, G46, and H (mining, utilities, wholesale trade excluding motor vehicles, and transportation and storage).
} 
the United States is by no means the most innovative among these countries by this measure, although this conclusion should be viewed with caution given the slight noncomparability of the U.S. data. ${ }^{6}$

How does the aggregate innovation picture compare with aggregate productivity measures? To answer this question, I compared the innovation rates at the country level with overall labor productivity (GDP per hours worked, also from OECD data). The results are shown in Figure $3 .{ }^{7}$ With the exception of an outlier (Norway), the share of both SMEs and large firms that innovate appears to be positively related to labor productivity at the country level. Simple univariate regressions for the relationship were moderately significant, and even more so when robust methods such as Least Absolute Deviations or Least Median of Squares were used.

Although the correlation displayed should not be taken too seriously, given the number of confounding influences and differences in industrial structure across countries, even at the aggregate level there does seem to be a relationship between innovative activity by firms and productivity, albeit one that leaves room for many other influences. It is natural to ask how this relationship comes about - what actions by individual firms lead to aggregate productivity improvements? One can think of two main channels by which the presence of more innovative firms can translate into productivity improvements: first, innovation in existing firms can both increase their efficiency and improve the goods and services they offer, thus increasing demand as well as reducing costs of production. Second, innovating firms are likely to grow more than others and new entrants with better products to offer are likely to displace existing inefficient firms, with a concomitant increase in aggregate productivity levels. In both cases the relationship between innovation and productivity is influenced by the institutional and macroeconomic environment in which the firms operate, possibly leading to substantial differences across countries in the relationship between them.

\footnotetext{
${ }^{6}$ Although the sampling frame for the BRDIS was the population of U.S. firms with 5 or more employees, this survey was the successor to the longrunning RD-1 survey which was only filled out by RD-doing firms, and the innovation questions were at the end of a long survey, most of which concerned R\&D. So there is some suspicion that they may not always have been accurately answered by non-R\&D-doers. This suggestion has been informally confirmed by conversations with the NSF. The product innovation rate for $3 \%$ of the firms that report doing R\&D in the BRDIS survey was $66 \%$, whereas the rate for non-R\&D-doers was $7 \%$. The gap, which is much larger than that in Europe, does suggest some undercounting for the non-R\&D firms.

7 The innovation rate is defined as the share of all firms in innovating sectors that have introduced any new process or product during the past three years, including organizational and marketing innovations. The data are from Eurostat's database for the sixth Community Innovation Survey, variable INNO.
} 
The present paper will review the ways in which economists have analyzed the relationship between productivity and innovation, focusing on the use of such innovation survey data as well as other data on innovative output such as patents. The differing measures of innovation (dummy variables, innovative sales, and innovation expenditure) that the various surveys yield will be reviewed and their drawbacks and advantages discussed. The distinction between innovation input (expenditures and choices under the control of the firm) and innovation output (depending on inputs but also with a large element of chance) is important and there are rationales for using both concepts.

After discussing measures of innovation, the paper will review two approaches to measuring the relationship between productivity and innovation: the econometric or regression approach and the growth accounting approach. Both are in their relative infancy due to the fact that the appropriate data has been lacking until quite recently (and is still not widely available).

\section{Innovation - the concept and its measurement}

There were two early empirical efforts which generated datasets on innovation that have been used in some studies (regrettably few studies, in fact). They are the SPRU study of UK firms begun in 1970, and conducted over a period 15 years through 1984 (Freeman and Soete 1997) and the study by Acs and Audretsch during the 1980s that looked at US firm innovations. The SPRU study asked almost 400 experts in industry to identify significant technical innovations that were commercialized in the UK sometime between 1945 and 1983 and then surveyed the firms that had introduced the innovations. The database contains over 4000 innovations, almost all of which are in the manufacturing sector. It has been used to show that the relationship between innovative activity and firm size is largely U-shaped, and that smaller firms show greater innovative activity than they do formal R\&D activity (Pavitt et al. 1987). A couple of the papers surveyed below (Geroski 1989 and Sterlacchini 1989) make use of this database, but it has not been exploited extensively in the analysis of innovation and productivity.

The 1990 Acs and Audretsch study for the US Small Business Administration (SBA) was based on a survey of over 100 trade journals in 1982 that looked for announcement of the market introduction of inventions. The definition used by the SBA was the following:

"a process that begins with an invention, proceeds with the development of the invention and results in introduction of a new product, process or service to the marketplace"

This survey yielded over 8000 US innovations, most if which probably dated to 1978-1982, but all of which were introduced in 1982. Acs and Audretsch use these data to analyze the 
role of small firms in innovation, the growth of firms, and the evolution of market structure. Unfortunately they do not provide any analysis of the relationship between these invention introductions and firm productivity.

Both the SPRU and the SBA surveys used the innovation as the unit of observation, and any firm-level analysis using these data is therefore based only on innovative firms. In contrast, the innovation surveys described below are conducted at the firm level and sometimes collect data on non-innovative firms as well. Thanks to work by the OECD and others, we now have a definition of innovation done by firms that is fairly standard across a wide range of countries and surveys:

"An innovation is the implementation of a new or significantly improved product (good or service), or process, a new marketing method, or a new organisational method in business practices, workplace organisation or external relations."

Most of the work on innovation described in this paper has been based on surveys that use a version of this definition. Thus there has been consistency in the definition of the innovation variables across study, although perhaps not consistency in the interviewees' understanding of the definition. However, note that there is at least one slightly ambiguous feature of the definition, in that it does not define "new" very precisely. Some of the surveys have made a distinction between "new to the firm" innovations and "new to the market" innovations, which can be a way of distinguishing more radical innovation from imitation. But in general, the interpretation of "new" is left to the survey respondent.

In spite of the apparent clarity of the definition of innovation in the Oslo Manual, measuring innovation in a form that is useful for statistical analysis has proved challenging. The central problem is that no two innovations are alike. Some innovations (e. g., the invention of the telephone or perhaps the telegraph) create a whole new market sector whereas others are useful but trivial, and there is a wide range in between. In general we can say that smaller innovations are more numerous than game-changing ones. As shown in Table 1, this fact is very visible in the data collected by Acs and Audretsch. During the year 1982, over 85 per cent of the innovations they identified were modest improvements to existing products, and none created entire new markets. Fewer than 2 per cent were considered even the first of its type on the market in existing market categories. ${ }^{9}$

${ }^{8}$ Oslo Manual (OECD 2005), third edition, p. 46.

${ }^{9}$ Note that by using the 1982 date, Acs and Audretsch did miss two major innovations: the IBM personal computer and Microsoft DOS, both of which were introduced in 1981 and which arguably meet the definition of "created entire new market". 
The innovation surveys have typically measured innovation in two ways: first, by asking whether the firm introduced an innovation of a certain type (product, process, organisational, marketing, etc.) during a preceding period (usually the past three years) and second, by asking what share of the firm's sales are due to products introduced during the same preceding period. The first measure has a number of drawbacks, which have become quite evident as it has been used in many empirical studies. When examined across a range of firm sizes, it produces the misleading results that larger firms are more likely to be innovative, whereas in truth larger firms are involved in a wider range of activities and therefore more likely to have an innovation in at least one of them. So this variable cannot be used to make the kind of statements that one sometimes hears, such as "large firms are more innovative than small firms."

Another problem is the previously mentioned unequal size of innovations and the failure in some surveys to distinguish between "new to the market" and "new to the firm." Based on the Acs and Audretsch results we know that many more of the innovative firms will have introduced improvements to existing products rather than entirely new goods and services, but the latter may be more important than the former. This view of the "skewness" of innovation values is supported by a large amount of research on the valuation of patented inventions (Harhoff et al. 1999; Scherer and Harhoff 2000; Hall et al. 2005). Although patented inventions are not precisely the same as innovations, they are similar and share some of their distributional properties, with the majority worth very little, and a few that are quite valuable to their owners.

Because of the imprecision and noisiness of the innovation dummies, many researchers prefer to use the second measure, the share of sales of innovative products, which does give a good indication of how important the innovation(s) were overall for the firm in question. Unfortunately, this measure is useful only for goods and services and cannot be used to capture process or organisational innovation. Nevertheless, it is the one relied on by more than half of the papers discussed in the following sections, often accompanied by a dummy for process innovation. Only one example exists where firms were asked to quantify the impact of process innovation on cost reduction (Peters 2006, for Germany).

\section{Productivity - the concept and its measurement}

What we mean by the term "productivity" is fairly easy to understand although difficult to measure: it is the quantity of output that can be produced using a given level of inputs. At this level of the definition, there is not even a presumption of optimality or efficiency in production. However, normally we assume that the entity whose productivity we wish to measure is "efficient" in the sense that it is using the minimum necessary level of inputs to produce a certain level of output, given its level of technological knowledge, its 
organization, its size, and other endowments, as well as the environment in which it operates.

Economists generally describe the relationship between output and the level of inputs using a production function, of which the most convenient for analysis is the following: ${ }^{10}$

$$
Q=A C^{\alpha} L^{\beta}
$$

Where $Q$ is output, $C$ is the level of capital stock, and $L$ is labor (and potentially other noncapital inputs). ${ }^{11} A$ is the overall level of productivity which may vary across entities. That is, because of organizational differences, frictions, or other constraints, entities with identical levels of $C$ and $L$ may not be able to achieve the same level of output $Q$.

For measurement purposes, the logarithm of equation (1) is taken:

$$
q_{i t}=a_{i t}+\alpha c_{i t}+\beta l_{i t} \quad i=\text { entity, } t=\text { time }
$$

where the added subscripts denote the fact that productivity levels are usually measured for a number of entities over several time periods. Equation (2) yields an expression for total factor productivity (usually denoted TFP):

$$
T F P \equiv a_{i t}=q_{i t}-\alpha c_{i t}-\beta l_{i t}
$$

All well and good, but measuring TFP therefore requires measures of real output $Q$, real capital stock $C$, and labor input $L$ (as well as possible other inputs, such as energy and materials), to say nothing of the coefficients $\alpha$ and $\beta$. I discuss the latter problem first.

There are two widely used approaches to estimating the weights $\alpha$ and $\beta$ to be applied to the inputs in the productivity measure: 1 ) assume that input markets are competitive, which implies that the coefficients are the shares of revenue received by each of the factors; ${ }^{12}$ and 2) assume the coefficients are (roughly) constant across entities and estimate

10 I ask the well-informed reader for patience with the elementary review provided here, which is primarily for the purpose of setting notation for the subsequent discussion.

11 The treatment here has been greatly simplified by omitting purchased inputs (such as materials, energy, etc.). In practice these inputs are more important on a share basis than either capital or labor and need to be included in estimation (typically accounting for about 0.7 of the inputs). Alternatively, one can measure output as value added, which is usually defined as output less purchased inputs. The precise choice of what to include or exclude depends to some extent on data availability, and several variations have been pursued in the literature discussed here. In particular, many of the available datasets do not include measures of the firm's capital stock and researchers are forced to resort to proxies such as current investment spending.

12 This approach can be modified to account for scale economies and market power as in R. Hall (1988), or indeed almost anything that implies homogeneity of some degree in the production function. See below for a modification that allows the firms to have some degree of market power. 
them via regression. Solution (1) is favored by statistical agencies and others who simply need a measure of TFP for an individual entity and may not have a sample available for estimation, and solution (2) is the one typically used by econometricians and the main one employed in the literature discussed later in this paper, although there are some exceptions. ${ }^{13}$

The second problem, how to measure the inputs and outputs themselves, is subject to a multitude of solutions. Unfortunately, the choices can have considerable impact not only on the measurement of TFP but also on the relation of that measure to innovation. The difficulty lies in the measurement of real inputs and outputs, holding constant the unit of measure over time. To take a concrete and well-known example, computers, which are a component of capital, have changed considerably over time. If we measure their contribution to the inputs simply as expenditure on computers, it is likely to be roughly constant over time, and TFP will grow as the computers become more productive. However, if instead we deflate the computer expenditure by an index of the effective price of computing power, which has fallen dramatically over the past 30 years, the real quantity of computers will grow substantially during the same period, and TFP growth will be correspondingly less. In essence, some technical change or innovation has been transferred from TFP to its inputs. ${ }^{14}$ The same argument applies to the labor input, where quality has probably generally increased over time so that a person-hour 30 years ago is not the same as one today. All this means that TFP measures need to be used carefully, with an understanding of the approach used to deflation and quality adjustment. ${ }^{15}$ That is, much of the effects of innovation may show up as higher quality inputs if they are quality adjusted, and will not appear in output.

For the output measure, the problem is even more striking when we look at the level of the firm or enterprise, because of the potential for variations in market power across firms,

\footnotetext{
${ }^{13} \mathrm{~A}$ large literature has developed on the methodologies for estimating the production function in the presence of simulateneity between input and output choice and errors of measurement. Some key papers are Blundell and Bond (2000), Griliches and Mairesse (1984), and Olley and Pakes (1996).

14 Of course, if the analysis is done at the aggregate level, the production of computers will be in the output measure, and their share of TFP will increase. See Denison (1966) and Jorgenson and Griliches(1967) for discussion of this point.

15 On the output side, Hall (1996), Mairesse and Hall (1996), and Griliches (1994) present R\&D-productivity regressions that illustrate the effect a properly measured computing sector deflator can have on the measured returns to R\&D via its impact on the measurement of TFP. Those authors show that using a hedonic price deflator for computing rather than an overall GDP deflator more than triples the elasticity of output with respect to R\&D, from 0.03 to 0.11 . That is, most of the returns to R\&D during the period estimated (1980s) went to price reduction and real output increase, and very little was received by the firms in the form of increased revenues. See also OECD (2003), pp. 43-44 for a discussion of this issue.
} 
and for the role that innovation plays in creating and/or increasing that market power. The easiest way to see this is to rewrite the TFP equation in terms of revenue rather than real output, under the assumption of an iso-elastic demand equation. The idea behind this approach is that each firm produces differentiated products and therefore faces its own downward sloping demand curve. Firms have idiosyncratic output prices, so that deflation of revenue by an overall deflator simply yields real revenue rather than an actual output measure. I denote the log of real revenue by $r_{i t}$ and the log of the firm's output price by $p_{i t}$, with $r_{i t}=p_{i t}+q_{i t}$. Write the iso-elastic demand equation facing the firm in logarithmic form as follows: 16

$$
q_{i t}=\eta p_{i t}
$$

where $\eta$ is the (negative) demand elasticity. Combining equations (2) and (4) yields the following expression for the (observable) revenue as a function of the inputs and TFP:

$$
r_{i t}=\frac{\eta+1}{\eta}\left(a_{i t}+\alpha c_{i t}+\beta l_{i t}\right)
$$

The above equation implies that the estimated coefficients of capital and labor in the productivity equation will be negative if demand is inelastic $(0>\eta>-1)$ and biased downward if demand is elastic $(\eta<-1)$. As $\eta$ approaches - $\infty$ (perfectly elastic, or pricetaking), the bias disappears and the equation is identical to equation(2), but with revenue in place of output.

The conclusion is that if a regression based on equation (5) is used to estimate TFP $\left(a_{i t}\right)$, the estimate will typically be biased downward over a reasonable range of demand elasticities. Note also that for a profit-maximizing firm, the bias is equal to 1-m, where $m$ is the markup. The further we are from perfect competition $(m=1)$ and the higher the markup, the greater is the downward bias. After I present the basic model that relates innovation and productivity in the next section, I will derive the implications of equation (5) for the measurement of that relationship.

\section{Modeling the relationship}

When looking at the contribution of innovative activity to productivity, the usual starting point is to add a measure of the knowledge or intangible capital created by innovative activity to the production function:

\footnotetext{
16 This treatment of the problem is drawn from Griliches and Mairesse (1984). Also see Mairesse and Jaumandreu (2005) and Foster et al. 2008 for discussions of the differences between revenue productivity estimation and true productivity estimation.
} 


$$
Q=A C^{\alpha} L^{\beta} K^{\gamma}
$$

Here $K$ is some kind of proxy for the knowledge stock of the firm. $K$ can stand for a number of aspects of the entity's innovative capability: its technological knowledge obtained via $\mathrm{R} \& \mathrm{D}$, its competency at transforming research results into useful products and processes, and so forth. It can even be based on innovative success rather than capability. Traditionally $\mathrm{K}$ has been measured as a stock of past R\&D spending but as other kinds of data have become available, other measures involving patents or innovation indicators have been used.

As before, the logarithm of equation (1) is taken:

$$
q_{i t}=a_{i t}+\alpha c_{i t}+\beta l_{i t}+\gamma k_{i t} \quad i=\text { entity, } t=\text { time }
$$

Because much of innovative activity is directed towards new products and product improvement, it is useful to rewrite the demand equation to allow the knowledge stock to shift the demand curve facing the firm:

$$
q_{i t}=\eta p_{i t}+\varphi k_{i t} \quad \varphi>0
$$

Assuming that the knowledge stock has a positive coefficient implies that the effect of increased knowledge or innovative activity is to shift the demand curve out by making the firm's products more attractive to its customers, at a given price.

Combining equations (7) and (8) as before, we obtain the following equation for revenue:

$$
r_{i t}=\left(\frac{\eta+1}{\eta}\right)\left(a_{i t}+\alpha c_{i t}+\beta l_{i t}\right)+\left(\frac{\gamma(\eta+1)-\varphi}{\eta}\right) k_{i t}
$$

This equation shows that knowledge stock $K$ is likely to contribute to revenue and therefore to measured productivity growth via two channels: directly by increasing the efficiency of production and indirectly by shifting the demand curve for the firm's products outward (note that $\eta$ is negative so that $-\varphi / \eta$ is positive). It is usual to think of these two channels as process and product innovation.

For full identification of the system implied by equation (9), it would be desirable either to have data on individual firm output prices to allow separate estimation of $\eta$ and $\varphi$ or to have some information on the components of $\mathrm{K}$ that might be directed toward processes and/or products. ${ }^{17}$ At the simplest level, one can gain some idea of the relative importance

\footnotetext{
${ }_{17}$ Mairesse and Jaumandreu (2005) compare productivity estimates using revenue and output deflated at the firm level for France and Spain. They do not find significant differences in the estimates, but they did not
} 
of the two types of innovation for productivity using the innovation dummy variables available from the various innovation surveys. One implication of the foregoing model is that process innovation will have ambiguous effects on revenue productivity, effects that depend on the firm's market power, whereas the effect of product innovation is likely to be positive.

In the studies reviewed here, the estimation of equation (9) is generally performed by regressing a measure of log revenue per employee $\left(r_{i t}-l_{i t}\right)$ on the logs of capital or investment, firm size measured in terms of employment, and various proxies for innovative activity. Industry dummies at the two-digit level are almost always included, to control for things such as omitted inputs (in cases where value added is not available), differences in vertical integration, the omission of capital stocks (in cases where only current investment is available), and the overall level of technological knowledge. Although the model is in terms of the stock of knowledge or innovative capability, the usual proxies for this variable are the current level of innovative activity, measured as a dummy for some innovation during the past three years, or as the share of products sold that were introduced during the past three years. Because the estimation is almost always cross sectional, the fact that a flow of innovation rather than a stock is used will make little difference to the interpretation of the estimates, provided that innovation is persistent within firms. See Peters (2009) for evidence that this is the case.

\section{The empirical evidence}

Appendix Tables 1 and 2 summarize the studies which have attempted to estimate a quantitative relationship between firm-level productivity and innovation measures explicitly. ${ }^{18} 25$ papers are listed, of which all but two use data from the Community Innovation Survey (CIS) or its imitators in other countries. Of those using CIS-type data, 18 use some variant of the well-known CDM (Crepon, Duguet, and Mairesse) model for the analysis. One of these papers used both levels and growth rates to measure productivity (Loof and Heshmati 2006), but most have chosen either levels (14 papers) or growth rates (10 papers) exclusively.

Use of the CDM model implies that most of the estimates are essentially cross-sectional ones that ignore issues of the timing of innovation and its contribution to productivity (exceptions are Masso and Vahter 2008, Belderbos et al 2004, Peters 2006). This is a reflection of the nature of the innovation surveys, which ask about innovative behavior during the past three years and contain or are matched to other firm information that is

include R\&D in the equation nor do they have true quality-adjusted price deflators. These two facts may account for the difference between their finding and that of Mairesse and Hall (1996) for the US.

${ }^{18}$ The table ignores the large literature which studies R\&D and productivity; see Hall, Mairesse, and Mohnen 2010 for a recent survey of this topic. 
contemporary with the innovation data. The data available are usually not sufficient to construct a time series (panel) for the firms involved since the samples are redrawn for each survey and there is little overlap. ${ }^{19}$ Thus the analysis usually relates productivity in one period to innovation in the same period or slightly before that period but does not trace out any dynamic response. It is noteworthy that the results for the papers that do use lagged measures of innovation are not notably different from those using contemporary measures, reinforcing the cross-sectional and long run nature of these results.

The CDM model has been described by many others in detail (see the references in appendix Tables 1 and 2) and I will only summarize it here. It generally consists of three sets of relationships, the first two of which can involve more than one equation. The first set of equations describes whether a firm undertakes R\&D and if so, how much, as a function of firm and industry characteristics. The second set describes the various types of innovation outcomes as a function of R\&D intensity and other firm/industry characteristics. In many cases, the R\&D variable in the innovation equations is computed as the expected R\&D intensity given the firm's characteristics. This procedure is grounded on the idea that many firms do informal R\&D but do not report their spending separately to the statistical agency performing the survey. In a sense, the model fills in their R\&D values with what might have been expected given their size, industry, nature of competition, etc. Looked at another way, including the fitted value of R\&D intensity for firms that actually report R\&D is a form of instrumental variable estimation of the innovation equations, which helps to correct for the simultaneity that might be present due to the fact that innovation is measured over the past three years, whereas frequently R\&D is a current year measure.

The innovation equations in the CDM model can be probit equations for the probability of product, process, or organizational innovation or they can also include an equation for the share of innovative sales (typically the sales share of products introduced during the past three years). In the latter case, the variable is sometimes transformed using logit transform which allows for infinite rather than finite support. That is, if $z$ is the share, ranging from 0 to 1 , the logit transform $\log (z /(1-z)) \in(-\infty,+\infty)$ is used. ${ }^{20}$ Following the logic used above, the predicted innovation probabilities or shares are then included in a productivity

\footnotetext{
${ }^{19}$ For example, Criscuolo and Haskell (2003) report that there are 1596 manufacturing firms in their CIS2 sample and 4567 in their CIS3 sample, but only 509 appear in both surveys. Hall, Lotti, and Mairesse (2008) have 9,462 firms in their sample drawn from three MCC surveys, but only 608 of these firms appear in all three surveys.

20 The alert reader will note that this expression is undefined for $z=0$ and $z=1$. Normally this problem is solved by setting $z=0.01$ and $z=0.99$ respectively.
} 
equation. The resulting estimates give the contribution of expected innovation conditional on $R \& D$ and other firm characteristics to productivity.

Tables 2a (levels, using innovative sales share), 2b (levels, using the product innovation dummy), and 3 (growth rates) summarize the results of estimating the productivityinnovation relationship from the papers listed in the appendix tables. I discuss each of these tables in turn. It should be noted that although I am treating the estimates as comparable, the precise regressions used in any particular paper will differ from those in other papers, as will the data construction itself. In addition, most researchers have included innovation variables that are predicted values from earlier regressions, as in the CDM model, while a few have included the actual innovation variables from the survey.

In spite of these variations, the results for the elasticity of output with respect to the innovative sales share (shown in Table $2 \mathrm{a}$ ) are reasonably consistent across countries and time periods. The highest elasticities (0.23-0.29) are for knowledge-intensive or high technology sectors. Most of the elasticities for Western Europe lie between 0.09 and 0.13, and less-developed countries, the service sector, and the low technology sectors have elasticities less than 0.09, with the exception of the insignificant estimate for Chilean data. Thus we can conclude that innovative sales are associated with revenue productivity, and that the association is stronger for higher technology sectors. For a typical Western European manufacturing firm, doubling the share of innovative sales will increase revenue productivity by about 11 per cent.

Table $2 b$ presents the results of the productivity regression that uses a $0 / 1$ measure of product innovation instead of the innovative sales share. For reasons mentioned earlier, this measure will vary by size of firm purely for measurement reasons and should be considered a much weaker proxy for innovative output. We do see that the results are more variable, although still positive for the most part. For manufacturing sectors in Western Europe, typical values are around 0.05-0.10, implying that product innovating firms have an average productivity that is about 8 per cent higher than non-innovators, but there is a wide dispersion.

The results for process innovation in both Tables $2 \mathrm{a}$ and $2 \mathrm{~b}$ are even more variable, with some negative, some zero, and some positive. Note that the few positive estimates in Table $2 \mathrm{a}$ are for the two cases where the authors included this variable alone in the productivity regression, without the innovative sales variable (Mairesse et al. 2005 for France and Siedschlag et al. 2010 for Ireland). The other positive estimates occur when product innovation is measured by a dummy rather than by the share of innovative sales, which suggests that they are partly due to the measurement error implicit in using a dummy to proxy for innovation. That is, we know from many of the surveys that process and product 
innovation go together. Therefore if we have a weak measure of product innovation, we might expect that the process innovation dummy would pick up more of the overall innovative activity. Recalling the discussion of equation (9), one could argue that the estimates in Table $2 \mathrm{a}$, which are mostly negative for process innovation and positive for product innovation, suggest that firms are operating in the inelastic portion of their demand curves and that revenue productivity is enhanced mainly by the introduction of new and improved products, and not by efficiency improvements in the production process. $^{21}$

Table 3 presents results for a productivity regression where the left hand side is productivity growth, rather than its level. This relationship is not precisely the growth rate version of the regressions that lie behind Table 2, since it relates growth to the level of innovative activity, not to its growth rate. In general, the results are similar to but slightly lower than the level version of the equation, with an innovative sales elasticity focused on the range $0.04-0.08$, and a product innovation dummy of about 0.02 . As before, process innovation is negative when included with product innovation in the equation, although positive on its own. It is noteworthy that the only study with a true estimate of the cost savings due to process innovation rather than a dummy (Peters 2006) yields a large and marginally significant elasticity of 0.14 , implying that if we had better measures of process innovation, we might be able to improve the measure of its impact considerably.

From this summary of the empirical relationship between the various innovation measures and firm-level revenue productivity we can conclude the following: first, there is a positive relationship, albeit somewhat noisy, between innovation in firms and their productivity both the level and its growth. Second, the positive relationship is primarily due to product innovation. The impact of process innovation is more variable, and often negative. This can be interpreted in one of two ways: the typical firm enjoys some market power and operates in the inelastic portion of its demand curve so that revenue productivity falls when it becomes more efficient. Alternatively, it is possible that there is so much measurement error in the innovation variables that only one of the two is positive and significant when entered in the productivity equation. Without instruments that are better targeted to predicting the two different kinds of innovation, this possibility cannot be ruled out.

21 The results surveyed here do not generally include the effects of organizational innovation, which has been shown to be associated with revenue productivity improvement, especially when accompanied by IT investment. However, in many cases the data available on organizational innovation (a simple dummy variable) do not allow researchers to include this variable along with the other innovation variables in productivity regressions, due to the collinearity of the various innovation variables previously referred to. 


\section{Conclusions}

The foregoing survey of empirical evidence on the relationship between innovation and productivity finds an economically significant impact of product innovation on revenue productivity and a somewhat more ambiguous impact of process innovation. As I have argued, the latter result is primarily due to the fact that we are not able to measure the real quantity effect of process innovation, which is the relevant quantity for social welfare. We can only measure the real revenue effect, which combines the impact of innovation on both quantity and price. So overall we can conclude that in spite of the fact that innovative activity is not very well measured in many cases, it does generally increase an individual firm's ability to derive revenue from its inputs.

Of course, this conclusion leads to new questions. What are the factors in the firm's environment that encourage such innovative activity? And how is aggregate productivity influenced by the innovative activities of individual firms? Although it is beyond the scope of this paper to answer these questions, some promising avenues to explore have been suggested recently in the literature. Taking the second question first, the approach of Foster, Haltiwanger, and Syverson (2008), although intensive in its data requirements, has yielded interesting insights on the relative importance of productivity growth in existing firms and net entry in aggregate productivity growth. In addition these authors perform a detailed analysis of the differences between revenue productivity growth and "physical" productivity growth, making the same distinction between efficiency and demand effects that I have made in this survey. They find that the use of revenue productivity will tend to understate the contribution of entrants to productivity growth, and that demand variation is a more important determinant of firm survival than efficiency in production.

A very interesting line of work would be to understand the extent to which innovative activity on the part of entrants and the existing firms is behind the results in Foster et al. (2008). That is, the paper provides evidence on the composition of aggregate productivity growth but not on its sources. Aghion et al. 2009 find that foreign firm entry in technologically advanced UK sectors spurs both innovation (measured as patents) and productivity growth, whereas entry by such firms in lagging sectors reduces innovation and productivity growth by domestic firms in those sectors, arguing that this is due to the fact that firms are discouraged by the cost of catching up. On the other hand, Gorodnichenko et al. 2010, using data from emerging market countries in Eastern Europe and the former Soviet Union, find a robust relationship between foreign competition (selfreported by the firms) and innovation in all sectors, including the service sector. Thus we have evidence that at least some kinds of entry encourage innovative activity, although relatively little that traces the path from entry to innovation and then to productivity. 
As to the regulatory and financial environment that encourages innovation on the part of firms, following important efforts led by the World Bank to collect data on entry regulation, the rule of law, and other country characteristics, a substantial cross country growth literature has developed that relates these characteristics to entry (Djankov et al. (2002); Aidis et al. 2009; Ciccone and Papaioannou 2006), investment (Alesina et al. 2003), productivity (Cole et al. 2005), and firm size and growth (Fisman and Sarria-Allende 2004; Klapper et al. 2006). Briefly summarized, stronger entry regulation and/or higher entry costs are associated with fewer new firms, greater existing firm size and growth, lower TFP, less investment, and higher profits. ${ }^{22}$ Most of the studies cited have made a serious attempt to find instruments or controls which allow them to argue that this relationship is causal. Thus far none of these studies explicitly looks at the impact on innovative activity and its relationship with productivity, although one can argue that the entry of new firms is a form of innovation. To get a full picture of the macro-economy that incorporates firm entry and exit, innovation, and the resulting productivity growth, a picture that would allow one to clearly understand the use of various policy levers, is a goal not yet achieved in the literature.

One avenue that looks promising is the work of Bartelsman, Haltiwanger, and Scarpetta (2009), who extended Foster et al. (2008) to look at the allocative efficiency of entry and exit by firms to data on firms in the US and seven European countries. They develop a relative diagnostic measure of inefficient allocation of resources across firms based on the covariance of firm size and productivity within industry. The idea of this measure is that economies that are subject to inefficient regulation that prevents firms from growing or shrinking to their optimal size will display a lower correlation between firm size and productivity, since more productive firms will not be able to grow and displace less productive firms. They show that this measure changed in the way one would expect in three East European countries between the early 1990s and the 2000s. However, in spite of its promise for analyzing the sources of aggregate productivity growth, this kind of work has formidable data requirements. It also does not yet incorporate any measure of innovation as a causal measure, but it seems that extending this approach might be useful for exploring the simultaneous relationship between innovation, regulation, and productivity.

22 See Djankov (2009) for a recent survey of this literature. 


\section{References}

Acs, Z. J., and D. B. Audretsch (1990). Innovation and Small Firms. Cambridge, MA: MIT Press.

Aghion, P., R. Blundell, R. Griffith, P. Howitt, and S. Prantl (2009). The effects of entry on incumbent innovation and productivity, Review of Economics and Statistics 91(1): 20-32.

Aidis, R., S. Estrin, and T. Mickiewicz (2009). Entrepreneurial Entry: Which Institutions Matter?, Discussion Paper No. 7278. (CEPR, London, UK).

Alesina, A., S. Ardagna, G. Nicoletti, and F. Schiantarelli (2003). Regulation and Investment, NBER Working Paper No. 9560. (NBER, Cambridge, MA).

Bartelsman, E. J., J. Haltiwanger, and S. Scarpetta (2009). Cross Country Differences in Productivity: The Role of Allocation and Selection, NBER Working Paper No. 15490. (NBER, Cambridge, MA).

Belderbos, R., M. Carree, and B. Lokshin (2004). Cooperative R\&D and firm performance, Research Policy 33: 1477-1492.

Benavente H., J. M. (2006). The role of research and innovation in promoting productivity in chile, Economics of Innovation and New Technology 15: 301-315.

Blundell, R., and S. R. Bond (2000). GMM Estimation with persistent panel data: an application to production functions, Econometric Reviews 19: 321-340.

Chudnovsky, D., A. Lopez, and G. Pupato (2006). Innovation and productivity in developing countries: A study of Argentine manufacturing firms' behavior (1992-2001), Research Policy 35: 266-288.

Ciccone, A., and E. Papaioannou (2006). Red Tape and Delayed Entry, CEPR Discussion Paper No. 5996. (CEPR, London, UK).

Cole, H. L., L. E. Ohanian, A. Riascos, and J. A. Schmitz, Jr. (2005). Latin America in the Rear View Mirror, Journal of Monetary Economics 52: 69-107.

Crepon, B., E. Duguet, and J. Mairesse (1998). Research, Innovation, and Productivity: An Econometric Analysis at the Firm Level, Economics of Innovation and New Technology 7: 115-156.

Criscuolo, C., and J. E. Haskel (2003). Innovation and Productivity growth in the UK: evidence from CIS2 and CIS3, CeRiBA Working Paper. (LSE, London, UK). 
Denison, E. F. (1966). Discussion of Jorgenson and Griliches, American Economic Review 56(1/2): 76-82.

Djankov, S. (2009). The Regulation of Entry: A Survey, World Bank Research Observer 24: 183-203.

Djankov, S., R. La Porta, F. Lopez-de-Silanes, and A. Shleifer (2002). The Regulation of Entry, Quarterly Journal of Economics 117: 1-37.

Duguet, E. (2006). Innovation Height, Spillovers and TFP Growth at the Firm Level: Evidence from French Manufacturing for Company Performance. Economics of Innovation and New Technology 15 (4/5): 415-442.

Fisman, R., and V. Sarria-Allende (2004). Regulation of Entry and the Distortion of Industrial Organization, NBER Working Paper No. 10929. (NBER, Cambridge, MA).

Foster, L., J. Haltiwanger, and C. Syverson (2008). Reallocation, Firm Turnover, and Efficiency: Selection on Productivity or Profitability?, American Economic Review 98(1): 394-425.

Freeman, C. and L. Soete (1997). The Economics of Industrial Innovation, third edition. (London: Pinter).

Geroski, P. A. (1989). Entry, Innovation and Productivity Growth, Review of Economics and Statistics 71: 572-578.

Gorodnichenko, Y., J. Svejnar, and K. Terrell (2010). Globalization and innovation in emerging markets, American Economic Journal: Macroeconomics 2: 194-226.

Griffith, R., E. Huergo, J. Mairesse, and B. Peters (2006 ). Innovation and Productivity in Four European Countries, Oxford Review of Economic Policy 22: 483-498.

Griliches, Z. (1998). R\&D and Productivity: The Econometric Evidence. Chicago, IL: Chicago University Press.

Griliches, Z. (1996). The discovery of the residual: A historical note. Journal of Economic Literature 34(3): 1324-1330.

Griliches, Z. (1994). Productivity, R\&D and the Data Constraint, American Economic Review 84: 1-23.

Griliches, Z. and J. Mairesse (1984). Productivity and R\&D at the Firm Level. In Z. Griliches (ed.), R\&D, Patents, and Productivity. Chicago, IL: Chicago University Press, 339-374. 
Hall, B. H. (1993). Industrial Research during the 1980s: Did the Rate of Return Fall?, Brookings Papers on Economic Activity Micro (2): 289-344.

Hall, B. H. (1996). The Private and Social Returns to Research and Development. In B. L. R. Smith, and C. E. Barfield (eds.), Technology, R\&D, and the Economy (Brookings Institution and American Enterprise Institute, Washington, DC).

Hall, B. H., A. B. Jaffe, and M. Trajtenberg (2005). Market Value and Patent Citations, Rand Journal of Economics 36: 16-38.

Hall, B. H., F. Lotti, and J. Mairesse (2009). Innovation and Productivity in SMEs: Empirical Evidence for Italy, Small Business Economics 33: 13-33.

Hall, B. H., F. Lotti, and J. Mairesse (2008). R\&D, innovation, and productivity: new evidence from Italian manufacturing microdata, Industrial and Corporate Change, 17 (July): 813-839.

Hall, B. H., J. Mairesse, and P. Mohnen (2010). Measuring the Returns to R\&D. In Hall, B. H. and N. Rosenberg, Handbook of the Economics of Innovation, pp. 1034-1076. Amsterdam and New York: Elsevier.

Hall, R. E. (1988). The relationship between price and marginal cost in U. S. Industry. Journal of Political Economy 96 (5): 921-947.

Harhoff, D., F. Narin, F. M. Scherer, and K. Vopel (1999). Citation Frequency and the Value of Patented Inventions, Review of Economics and Statistics 81: 511-515.

Huergo, E., and J. Jaumandreu (2004). Firms' age, process innovation and productivity growth, International Journal of Industrial Organization 22: 541-559.

Janz, N., H. Loof, and B. Peters (2003). Firm Level Innovation and Productivity - Is there a Common Story Across Countries? Mannheim, Germany: ZEW Discussion Paper No. 03-26.

Jefferson, G. H., H. Bai, X. Guan, and X. Yu (2006). R\&D Performance in Chinese industry, Economics of Innovation and New Technology 15: 345-366.

Jorgenson, D. W., and Z. Griliches (1967). The Explanation of Productivity Change, Review of Economic Studies 34: 249-283.

Klapper, L., L. Laeven, and R. Rajan (2006). Entry regulation as a barrier to entrepreneurship, Journal of Financial Economics 82: 591-629.

Loof, H., and A. Heshmati (2006). On the relationship between innovation and performance: A sensitivity analysis, Economics of Innovation and New Technology 15: 317344. 
Loof, H., A. Heshmati, R. Asplund, and S.-O. Nåås (2001). Innovation and Performance in Manufacturing Industries: A Comparison of Nordic Countries. Stockholm, Sweden: SSE/EFI Working Paper Series in Economics and Finance No.457.

Mairesse, J., and B. H. Hall (1996). Estimating the productivity of research and development in French and US. manufacturing firms: An exploration of simultaneity issues with GMM methods. In K. Wagner, and B. van Ark (eds), International Productivity Differences and Their Explanations (Elsevier-North Holland, Amsterdam), pp. 285-315.

Mairesse, J., and J. Jaumandreu (2005). Panel-data Estimates of the Production Function and the Revenue Function: What Difference Does It Make?, Scandinavian Journal of Economics 107: 651-672.

Mairesse, J. and P. Mohnen (2010). Using innovation surveys for econometric analysis, in B. H. Hall and N. Rosenberg (eds.), Handbook of the Economics of Innovation, Volume II. Amsterdam and New York: Elsevier, pp. 1129-1155.

Mairesse, J., P. Mohnen, and E. Kremp (2005). The Importance of R\&D and Innovation for Productivity: A Reexamination in Light of the 2000 French Innovation Survey, in Jacques Mairesse and Manuel Trajtenberg (eds.), Special issue of Annales d'Economie et de Statistique 79-80 in Memory of Zvi Griliches: 487-528.

Mairesse, J., and S. Robin (2010). Innovation and Productivity: a Firm-Level Analysis for French Manufacturing and Services Using CIS3 and CIS4 data (1998-2000 and 2002-2004). Paris, France: CREST-ENSAE.

Masso, J., and P. Vahter (2008). Technological innovation and productivity in late-transition Estonia: econometric evidence from innovation surveys, European Journal of Development Research 20: 240-261.

OECD/OCDE (2005). Oslo Manual: Guidelines for collecting and interpreting innovation data, third edition. Paris: OECD.

OECD/OCDE (2003). The Sources of Economic Growth in OECD Countries. Paris: OECD.

Olley, G. S., and A. Pakes (1996). The dynamics of productivity in the telecommunications equipment industry, Econometrica 64: 1263-1297.

Parisi, M. L., F. Schiantarelli, and A. Sembenelli (2006). Productivity, innovation and R\&D: Micro evidence for Italy, European Economic Review 50: 2037-2061.

Pavitt, K., M. Robson, and J. Townsend (1987). The Size Distribution of Innovating Firms in the UK: 1945-1983, Journal of Industrial Economics 35: 297-316. 
Peters, B. (2009). Persistence of innovation: stylised facts and panel data evidence, Journal of Technology Transfer 34: 226-243.

Peters, B. (2006). Productivity effects of innovation activities, Chapter 4 of Peters, B., Innovation and Firm Performance: An Empirical Investigation for German Firms, University of Würzburg: PhD thesis.

Polder, M., G. Van Leeuwen, P. Mohnen, and W. Raymond (2009). Productivity effects of innovation modes. The Hague: Statistics Netherlands Discussion Paper No. 09033.

Raffo, J., S. l'Huillery, and L. Miotti (2008). Northern and southern innovativity: a comparison across European and Latin American countries, European Journal of Development Research 20: 219-239.

Scherer, F. M., and D. Harhoff (2000). Technology Policy for a World of Skew-distributed Outcomes, Research Policy 29: 559-566.

Siedschlag, I., Z. Zhang, and B. Cahill (2010). The effects of the internationalisation of firms on innovation and productivity, ESRI Working Paper No. 363 (Economic and Social Research Institute, Dublin, Ireland).

Sterlacchini, A. (1989). R\&D, innovations, and total factor productivity growth in British manufacturing, Applied Economics 21: 1549.

Tanaka, N., M. Glaude, and F. Gault (2005). Oslo Manual: Guidelines for Collecting and Interpreting Innovation Data, Paris: OECD and Eurostat.

US National Science Foundation (2010). NSF releases new statistics on business innovation, SRS Info Brief NSF 11-300, Washington, DC, October.

van Leeuwen, G. (2002). Linking Innovation to Productivity Growth Using Two Waves of the Community Innovation Survey, OECD Science, Technology and Industry Working Papers 2002/8. (OECD/OCDE, Paris).

Van Leeuwen, G., and L. Klomp (2006). On the contribution of innovation to multi-factor productivity growth, Economics of Innovation and New Technology 15: 367-390. 
Figure 1: Innovating firms by size, as a share of all firms, 2006-2008

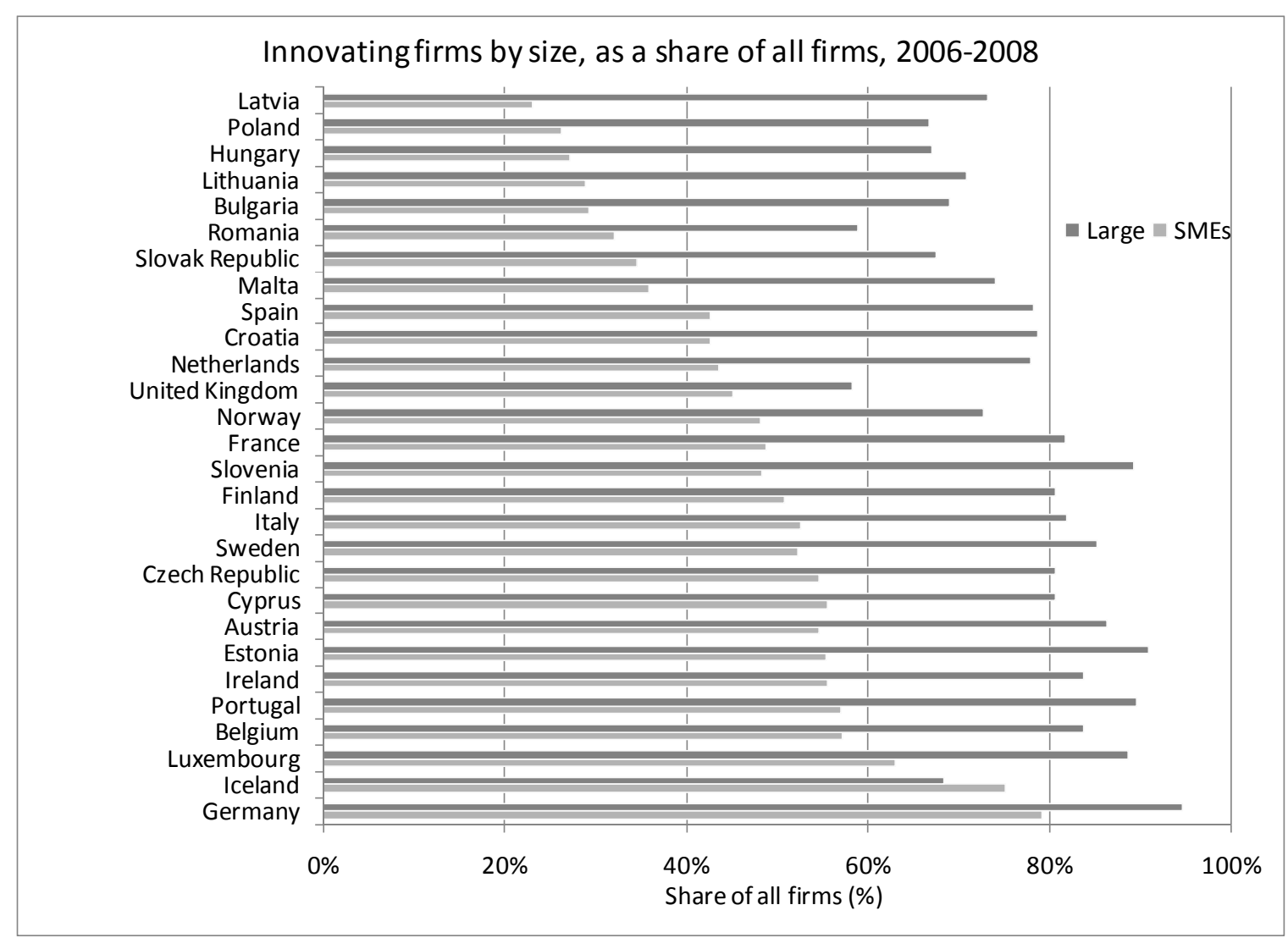

Source: Eurostat, CIS-2008, inn_cis6_prod. 
Figure 2: Innovating firms by type of innovation, as a share of all firms, 2006-2008

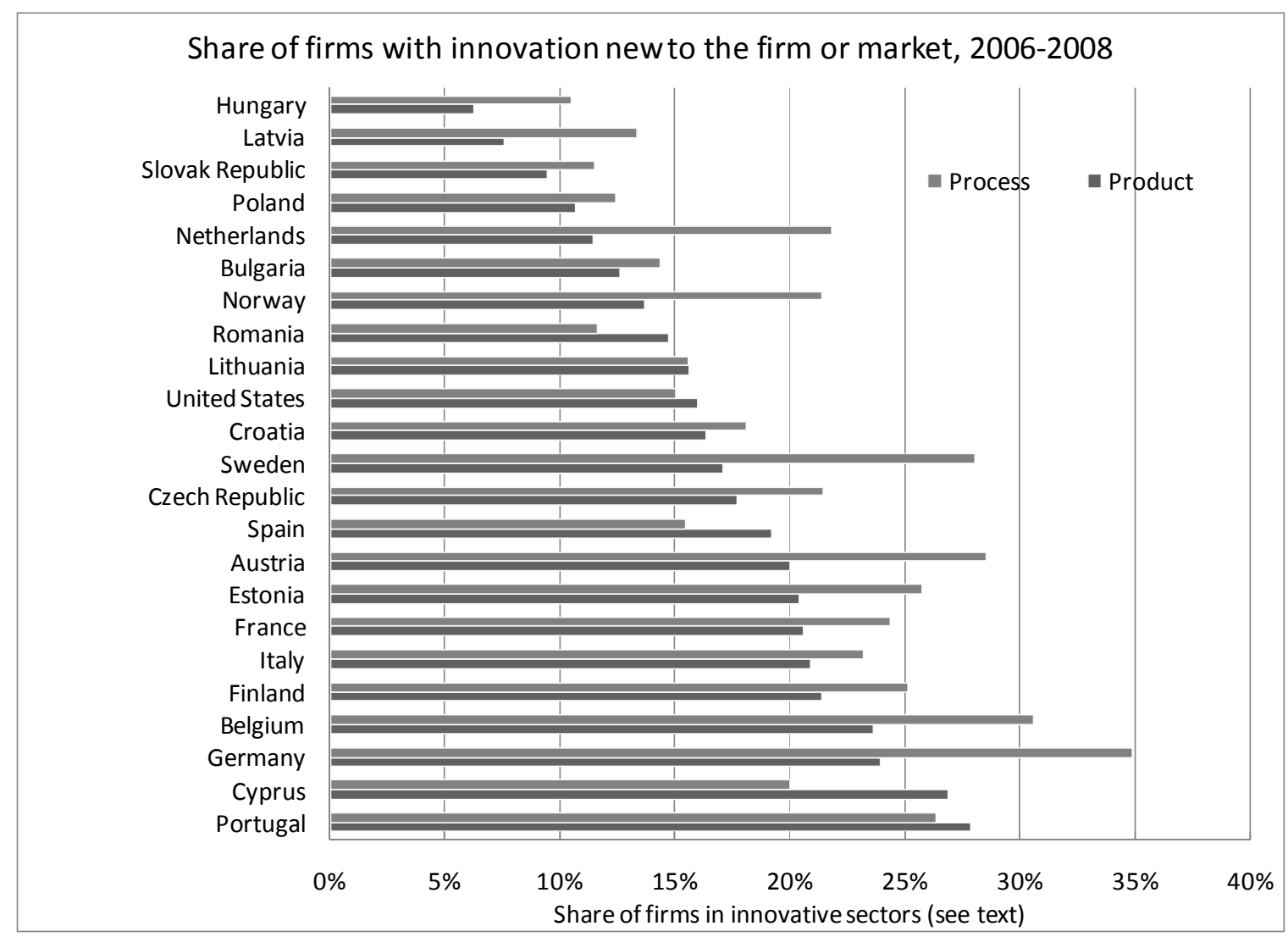

Source: Eurostat, CIS-2008, inn_cis6_prod; NSF InfoBrief 11-300, October 2010. 
Figure 3: Labor productivity levels and innovation, by country

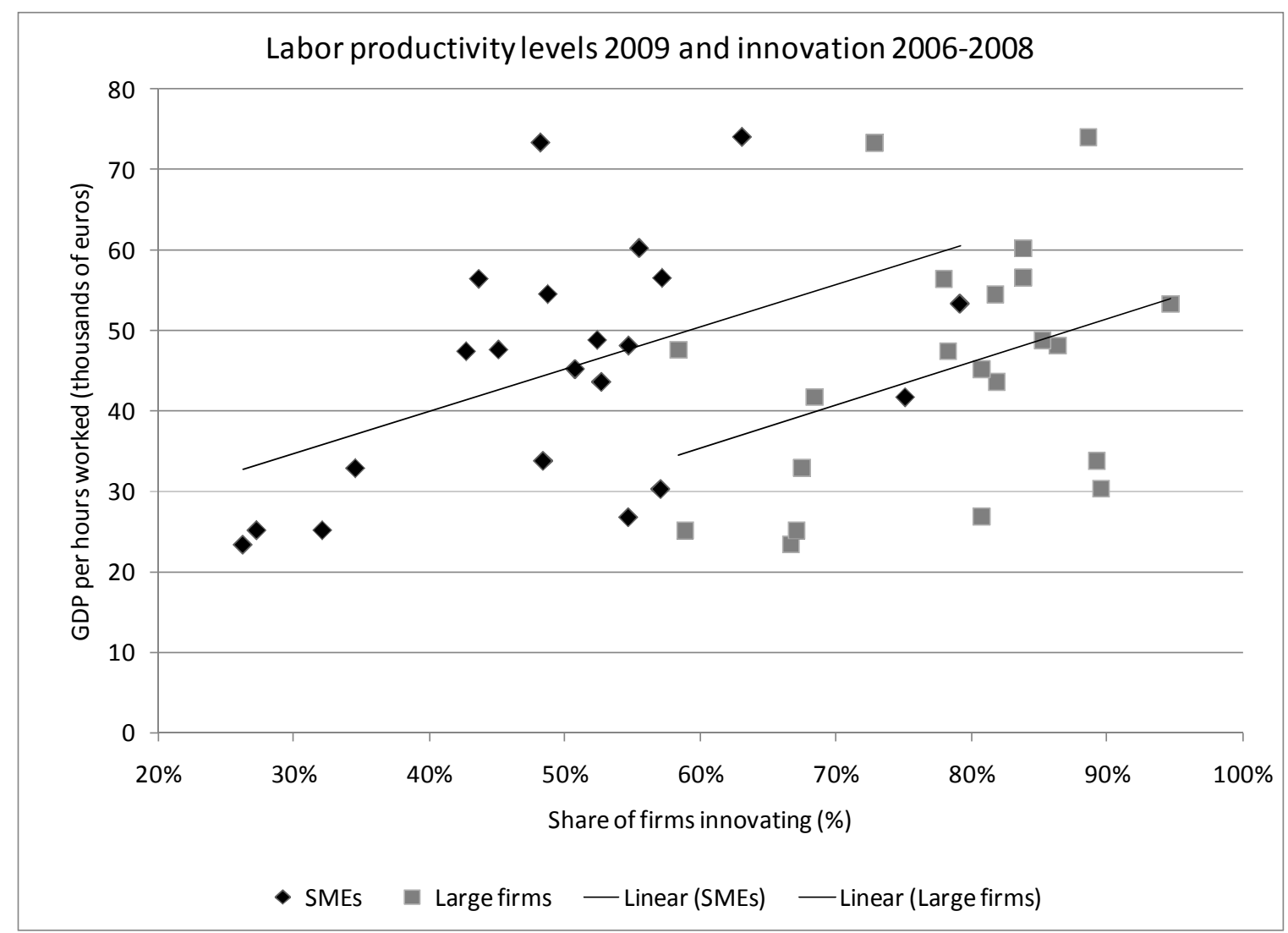

Source: OECD.stat and Eurostat, CIS 2008. 
Table 1: Manufacturing sector innovations by significance

\begin{tabular}{|c|c|c|c|c|}
\hline & \multicolumn{2}{|c|}{ Number } & \multicolumn{2}{|c|}{ Share } \\
\hline & $\begin{array}{l}\text { Large } \\
\text { firms }\end{array}$ & $\begin{array}{l}\text { Small } \\
\text { firms }\end{array}$ & $\begin{array}{l}\text { Large } \\
\text { firms }\end{array}$ & $\begin{array}{l}\text { Small } \\
\text { firms }\end{array}$ \\
\hline Establishes whole new categories & 0 & 0 & $0.00 \%$ & $0.00 \%$ \\
\hline $\begin{array}{l}\text { First of its type on the market in } \\
\text { existing categories }\end{array}$ & 50 & 30 & $1.76 \%$ & $1.43 \%$ \\
\hline $\begin{array}{l}\text { A significant improvement on } \\
\text { existing technology }\end{array}$ & 360 & 216 & $12.70 \%$ & $10.27 \%$ \\
\hline $\begin{array}{l}\text { Modest improvement designed to } \\
\text { update existing products }\end{array}$ & 2424 & 1858 & $85.53 \%$ & $88.31 \%$ \\
\hline Total & 2834 & 2104 & & \\
\hline
\end{tabular}

Source: Acs and Audretsch (1990), Table 2.3 
Table 2a: Results for the productivity-innovation relationship in TFP levels (product innovation measured as innovative sales share)

\begin{tabular}{llll} 
Sample & Time period & $\begin{array}{c}\text { Elasticity with } \\
\text { respect to innov } \\
\text { sales share }\end{array}$ & $\begin{array}{c}\text { Process innovation } \\
\text { dummy }\end{array}$ \\
\cline { 1 - 4 } Chilean mfg sector & $1995-1998$ & $0.18(0.11)^{*}$ & \\
Chinese R\&D-doing mfg sector & $1995-1999$ & $0.035(0.002)^{* * *}$ & \\
Dutch mfg sector & $1994-1996$ & $0.13(0.03)^{* * *}$ & $-1.3(0.5)^{* * *}$ \\
Finnish mfg sector & $1994-1996$ & $0.09(0.06)$ & $-0.03(0.06)$ \\
French mfg sector & $1986-1990$ & $0.07(0.02)^{* * *}$ & \\
French Hi-tech mfg \# & $1998-2000$ & $0.23(0.15)^{*}$ & $0.06(0.02)^{* * *}$ \\
French Low-tech mfg \# & $1998-2000$ & $0.05(0.02)^{* * *}$ & $0.10(0.04)^{* * *}$ \\
German K-intensive mfg sector & $1998-2000$ & $0.27(0.10)^{* * *}$ & $-0.14(0.07)^{* *}$ \\
Irish firms \# & $2004-2008$ & $0.11(0.02)^{* * *}$ & $0.33(0.08)^{* * *}$ \\
Norwegian mfg sector & $1995-1997$ & $0.26(0.06)^{* * *}$ & $0.01(0.04)$ \\
Swedish K-intensive mfg sector & $1998-2000$ & $0.29(0.08)^{* * *}$ & $-0.03(0.12)$ \\
Swedish mfg sector & $1994-1996$ & $0.15(0.04)^{* * *}$ & $-0.15(0.04)^{* * *}$ \\
Swedish mfg sector & $1996-1998$ & $0.12(0.04)^{* * *}$ & $-0.07(0.03)^{* * *}$ \\
Swedish service sector & $1996-1998$ & $0.09(0.05)^{*}$ & $-0.07(0.05)$ \\
\hline
\end{tabular}

Source: author's summary from Appendix Table 1.

\# Innovative sales share and process innovation included separately in the production function. 
Table 2b: Results for the productivity-innovation relationship in TFP levels (product innovation measured as a dummy)

\begin{tabular}{|c|c|c|c|}
\hline Sample & Time period & $\begin{array}{l}\text { Product innovation } \\
\text { dummy }\end{array}$ & $\begin{array}{l}\text { Process innovation } \\
\text { dummy }\end{array}$ \\
\hline Argentinian mfg sector & $1998-2000$ & $-0.22(0.15)$ & \\
\hline Brazilian mfg sector & $1998-2000$ & $0.22\left(0.04^{* * *}\right.$ & \\
\hline Estonian mfg sector & $1998-2000$ & $0.17(0.08)^{* *}$ & $-0.03(0.09)$ \\
\hline Estonian mfg sector & 2002-2004 & $0.03(0.04)$ & $0.18(0.05)^{* * *}$ \\
\hline French mfg sector & $1998-2000$ & $0.08(0.03)^{* *}$ & \\
\hline French mfg sector & $1998-2000$ & $0.06(0.02)^{* * *}$ & $0.07(0.03)^{* *}$ \\
\hline French mfg sector & $1998-2000$ & $0.05(0.09)$ & $0.41(0.12)^{* * *}$ \\
\hline French mfg sector & $2002-2004$ & $-0.08(0.13)$ & $0.45(0.16)^{* * *}$ \\
\hline French service sector & $2002-2004$ & $0.27(0.52)$ & $0.27(0.45)$ \\
\hline German mfg sector & $1998-2000$ & $-0.05(0.03)$ & $0.02(0.05)$ \\
\hline Irish firms \# & 2004-2008 & $0.45(0.08)^{* * *}$ & $0.33(0.08)^{* * *}$ \\
\hline Italian mfg sector & $1995-2003$ & $0.69(0.15)^{* * *}$ & $-0.43(0.13)^{* * *}$ \\
\hline Italian mfg sector SMEs & $1995-2003$ & $0.60(0.09)^{* * *}$ & $0.19(0.27)$ \\
\hline Mexican mfg sector & $1998-2000$ & $0.31(0.09)^{* *}$ & \\
\hline Spanish mfg sector & $2002-2004$ & $0.16(0.05)^{* * *}$ & \\
\hline Spanish mfg sector & $1998-2000$ & $0.18(0.03)^{* * *}$ & $-0.04(0.04)$ \\
\hline Swiss mfg sector & $1998-2000$ & $0.06(0.02)^{* * *}$ & \\
\hline UK mfg sector & $1998-2000$ & $0.06(0.02)^{* * *}$ & $0.03(0.04)$ \\
\hline
\end{tabular}

Source: author's summary from Appendix Table 1. 
Table 3: Results for the productivity-innovation relationship in TFP growth rates

\begin{tabular}{|c|c|c|c|c|}
\hline Sample & Time period & $\begin{array}{l}\text { Elasticity wrt Innov } \\
\text { sales share }\end{array}$ & $\begin{array}{l}\text { Product innovation } \\
\text { dummy }\end{array}$ & $\begin{array}{l}\text { Process innovation } \\
\text { dummy }\end{array}$ \\
\hline Argentinian mfg sector & $1992-2001$ & & $0.09(0.08)$ & $0.18(0.08)^{* *}$ \\
\hline Dutch mfg sector & 1994-1998 & $0.009(0.001)^{* * *}$ & & $-1.2(0.7)^{*}$ \\
\hline Dutch mfg sector & 1996-1998 & $0.0002 * * * \#$ & & \\
\hline French mfg sector & $1986-1990$ & & $0.022(0.004)^{* * *}$ & \\
\hline German mfg sector & $2000-2003$ & $0.04(0.02)^{* *}$ & & $0.14(0.08) * @$ \\
\hline Italian mfg sector & 1992-1997 & & $0.12(0.09)$ & $0.04(0.12)$ \\
\hline Spanish mfg sector & 1990-1998 & & $0.015(0.004)^{* * *}$ & \\
\hline Swedish mfg sector & 1996-1998 & $0.07(0.03)^{* *}$ & & \\
\hline Swedish service sector & 1996-1998 & $0.08(0.03)^{* * *}$ & & \\
\hline UK mfg sector & 1994-1996 & $-0.02(0.02)$ & & $0.02(0.01)^{*}$ \\
\hline UK mfg sector & $1998-2000$ & $0.07(0.03)^{* *}$ & & $-0.04(0.02)^{* *}$ \\
\hline
\end{tabular}

Source: author's summary from Appendix Table 1.

\# elasticity with respect to innovation expenditure per sales.

@ elasticity with respect to cost reduction per employee. 
Appendix Table 1: Empirical studies of the productivity-innovation relationship using productivity levels

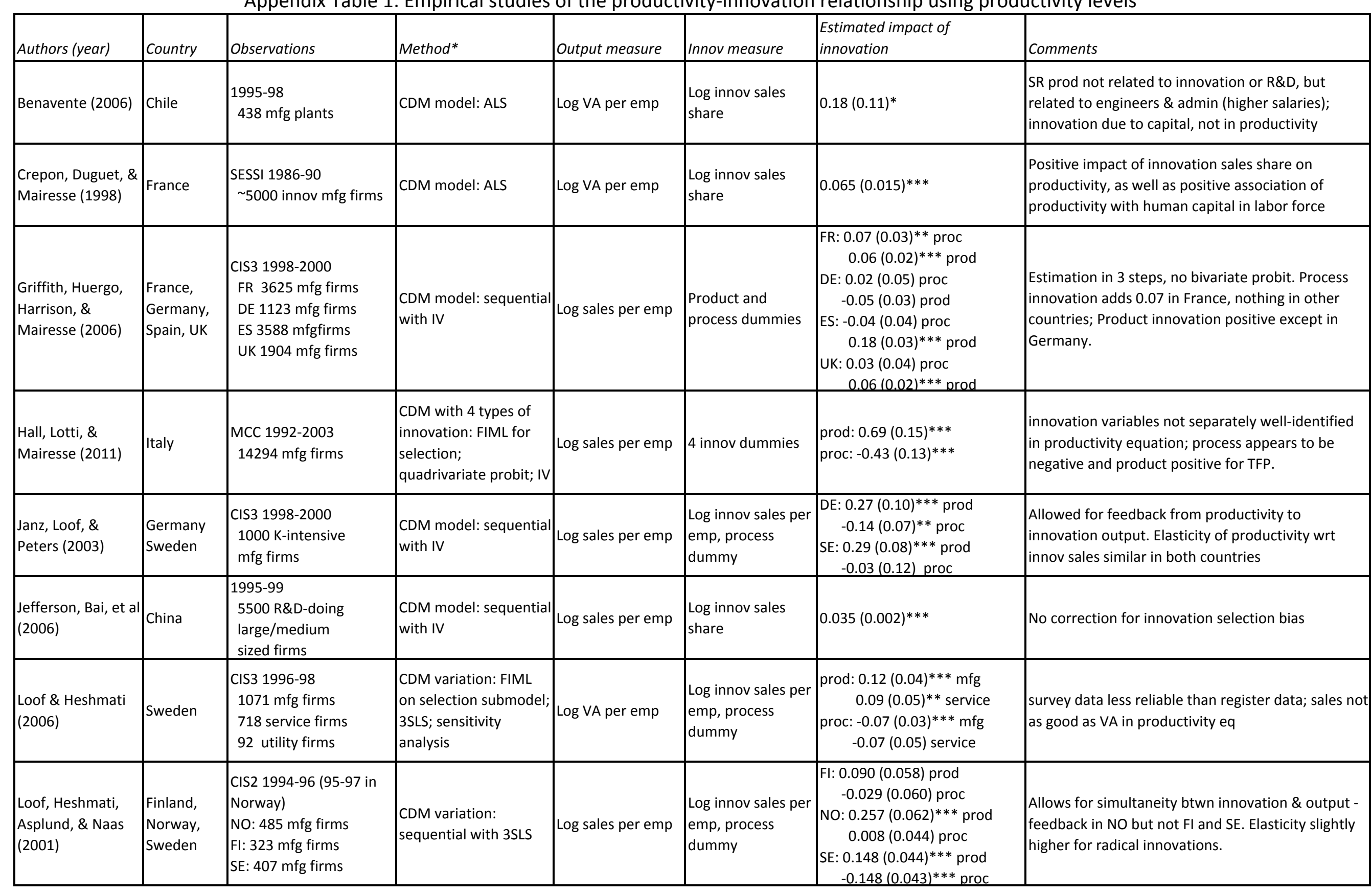




\begin{tabular}{|c|c|c|c|c|c|c|c|}
\hline $\begin{array}{l}\text { Mairesse \& Robin } \\
(2010)\end{array}$ & France & $\begin{array}{l}\text { CIS3 } 1998-2000 \\
3500 \mathrm{mfg} \text { firms } \\
\text { CIS4 2002-2004 } \\
5000 \mathrm{mfg} \text { firms } \\
3600 \text { service firms }\end{array}$ & $\begin{array}{l}\text { CDM model: FIML for } \\
\text { selection eqs; bivariate } \\
\text { probit; IV }\end{array}$ & Log VA per emp & $\begin{array}{l}\text { Product and } \\
\text { process dummies }\end{array}$ & \begin{tabular}{|l} 
mfg 98-00: \\
$0.41(0.12)^{* * *}$ proc \\
$0.05(0.09)$ prod \\
mfg 02-04: \\
$0.45(0.16)^{* * *}$ proc \\
$-0.08(0.13)$ prod \\
service: $0.27(0.45)$ proc \\
$0.27(0.52)$ prod
\end{tabular} & $\begin{array}{l}\text { Estimation is in } 3 \text { steps, but also in } 2 \text { steps, with } \\
\text { innov \& labor productivity equations combined. } \\
\text { Process innovation enters productivity, but not } \\
\text { product. Explores using a single innovation } \\
\text { indicator, which works just as well. }\end{array}$ \\
\hline $\begin{array}{l}\text { Mairesse, } \\
\text { Mohnen, \& Kremp } \\
\text { (2005) }\end{array}$ & France & $\begin{array}{l}\text { CIS3 1998-2000 } \\
2200 \mathrm{mfg} \text { firms }\end{array}$ & CDM \& variations & Log VA per emp & $\begin{array}{l}\text { Logit transform of } \\
\text { innov sales share, } \\
\text { process dummy, } \\
\text { other dummies - all } \\
\text { separately }\end{array}$ & \begin{tabular}{|c|} 
HT: $0.23(0.15)^{*}$ \\
$0.07(0.03)^{* * *}$ radical \\
$0.06(0.02)^{* * *}$ process \\
LT: $0.05(0.02)^{* * *}$ \\
$-0.08(0.05)^{*}$ radical \\
$0.10(0.04)^{* * *}$ process
\end{tabular} & $\begin{array}{l}\text { TFP using output ; going through innovation does } \\
\text { not add much to estimates of return to R\&D, after } \\
\text { correcting for selectivity and endogeneity; } \\
\text { endogeneity correction impt for innov variables }\end{array}$ \\
\hline $\begin{array}{l}\text { Masso \& Vahter } \\
(2008)\end{array}$ & Estonia & $\begin{array}{l}\text { CIS3 1998-2000 } \\
1467 \mathrm{mfg} \text { firms } \\
\text { CIS4 2002-2004 } \\
992 \mathrm{mfg} \text { firms }\end{array}$ & $\begin{array}{l}\text { CDM variation: } \\
\text { sequential with } \\
\text { bivariate probit for } \\
\text { innov }\end{array}$ & Log VA per emp & $\begin{array}{l}\text { Product and } \\
\text { process dummies } \\
\text { (org dummies in } \\
\text { 2nd period) }\end{array}$ & $\begin{array}{c}\text { prod 98-00: } 0.21(0.08)^{* * *} \\
\text { 02-04: } 0.00(0.05) \\
\text { proc 98-00: }-0.06(0.10) \\
\text { 02-04: } 0.15(0.06)^{* * *}\end{array}$ & $\begin{array}{l}\text { uses innov expenditure rather than R\&D; proc \& } \\
\text { prod dummies; prod innovation increases } \\
\text { productivity in recession; proc innovation in growth } \\
\text { period. One and two year lag effects are roughly the } \\
\text { same (cross sectional). }\end{array}$ \\
\hline $\begin{array}{l}\text { Masso \& Vahter } \\
\text { (2008) }\end{array}$ & Estonia & $\begin{array}{l}\text { CIS3 1998-2000 } \\
1467 \mathrm{mfg} \text { firms } \\
\text { CIS4 2002-2004 } \\
992 \mathrm{mfg} \text { firms }\end{array}$ & $\begin{array}{l}\text { CDM variation: } \\
\text { sequential with } \\
\text { bivariate probit for } \\
\text { innov }\end{array}$ & Log sales per emp & $\begin{array}{l}\text { Product and } \\
\text { process dummies } \\
\text { (org dummies in } \\
\text { 2nd period) }\end{array}$ & $\begin{array}{l}\text { prod 98-00: } 0.17(0.08)^{* *} \\
\text { 02-04: } 0.03(0.04) \\
\text { proc 98-00: -0.03 }(0.09) \\
\text { 02-04: } 0.18(0.05)^{* * *}\end{array}$ & $\begin{array}{l}\text { uses innov expenditure rather than R\&D; proc \& } \\
\text { prod dummies; prod innovation increases } \\
\text { productivity in recession; proc innovation in growth } \\
\text { period. One and two year lag effects are roughly the } \\
\text { same (cross sectional). }\end{array}$ \\
\hline $\begin{array}{l}\text { Polder, Van } \\
\text { Leeuwen et al } \\
\text { (2009) }\end{array}$ & $\begin{array}{l}\text { Nether- } \\
\text { lands }\end{array}$ & $\begin{array}{l}\text { CIS 3.5-4.5 2002-2006 } \\
\sim 1200 \mathrm{mfg} \& \text { service } \\
\text { firms }\end{array}$ & augmented CDM & Log VA per emp & $\begin{array}{l}3 \text { innov dummies } \\
\text { (proc prod org) in } \\
\text { combo }\end{array}$ & $\begin{array}{l}\text { mfg: } \\
1.7(0.4)^{* * *} \text { org alone } \\
1.0(0.5)^{* *} \text { org \& proc } \\
0.9(0.2)^{* * *} \text { all } \\
\text { serv: } \\
4.3(0.5)^{* * *} \text { org alone } \\
17.1(2.2)^{* * *} \text { org \& proc } \\
-8.3(1.3)^{* * *} \text { proc \& prod } \\
3.9(0.5)^{* * *} \text { all } \\
\end{array}$ & $\begin{array}{l}\text { Org innovation has strongest TFP effects. Process } \\
\text { and product, only when combined with org } \\
\text { innovation. However, signs of coefficient instability } \\
\text { due to correlation of } 8 \text { combinations when } \\
\text { predicted }\end{array}$ \\
\hline $\begin{array}{l}\text { Raffo, Lhuillery \& } \\
\text { Miotti (2008) }\end{array}$ & \begin{tabular}{|l|} 
France, \\
Spain, \\
Switzerland \\
, Argentina, \\
Brazil, \\
Mexico
\end{tabular} & $\begin{array}{l}\text { CIS3 1998-2001 mfg } \\
\text { AR } 1308 \text { firms } \\
\text { BR } 9452 \text { firms } \\
\text { MX } 1515 \text { firms } \\
\text { FR } 4618 \text { firms } \\
\text { CH } 925 \text { firms } \\
\text { ES } 3559 \text { firms } \\
\text { (2002-04) } \\
\end{array}$ & $\begin{array}{l}\text { CDM model: sequential } \\
\text { with IV }\end{array}$ & Log sales per emp & \begin{tabular}{|l} 
product \& \\
organizational \\
innov dummies
\end{tabular} & $\begin{array}{l}\text { AR: }-0.22(0.15) \\
\text { BR: } 0.22(0.04)^{* * *} \\
\text { MX: } 0.31(0.09)^{* * *} \\
\text { FR: } 0.08(0.03)^{* *} \\
\text { ES: } 0.16(0.05)^{* * *} \\
\text { CH: } 0.10(0.06)^{*}\end{array}$ & $\begin{array}{l}\text { Interaction of innovative activities with national } \\
\text { systems weaker in developing countries. Foreign } \\
\text { and domestic subs are uniformly more productive, } \\
\text { but do more R\&D only in France and Brazil. }\end{array}$ \\
\hline
\end{tabular}




\begin{tabular}{|c|c|c|c|c|c|c|c|}
\hline $\begin{array}{l}\text { van Leeuwen \& } \\
\text { Klomp (2006) }\end{array}$ & $\begin{array}{l}\text { Nether- } \\
\text { lands }\end{array}$ & $\begin{array}{l}\text { CIS2 1994-96 } \\
1400 \text { innov firms }\end{array}$ & CDM variation: 3SLS & Log sales per emp & $\begin{array}{l}\text { Process dummy; } \\
\text { innov sales share }\end{array}$ & $\begin{array}{l}\text { prod: } 0.13(0.03)^{* * *} \\
\text { proc: }-1.3(0.5)^{* * *}\end{array}$ & $\begin{array}{l}\text { Includes market share eq; feedback from sales to } \\
\text { innovation; revenue function approach better than } \\
\text { VA prod function framework (innov sales do not } \\
\text { enter VA function in the presence of R\&D and } \\
\text { markup coefficients). }\end{array}$ \\
\hline $\begin{array}{l}\text { Siedschlag, Zhang, } \\
\text { and Cahill (2010) }\end{array}$ & Ireland & $\begin{array}{l}\text { CIS3 2004-2006 } \\
\text { CIS4 2006-2008 } \\
723 \text { firms (balanced } \\
\text { panel) }\end{array}$ & $\begin{array}{l}\text { CDM variation: } \\
\text { sequential with IV }\end{array}$ & Log sales per emp & $\begin{array}{l}\text { Product, process, } \\
\text { and organizational } \\
\text { dummies, innov } \\
\text { sales share - all } \\
\text { separately }\end{array}$ & $\begin{array}{l}\text { innov sales: } 0.11(0.02)^{* * *} \\
\text { prod: } 0.45(0.08)^{* * *} \\
\text { proc: } 0.33(0.08)^{* * *}\end{array}$ & $\begin{array}{l}\text { Uses innovation expenditure instead of R\&D } \\
\text { spending; includes FDI and foreign ownership } \\
\text { characteristics. }\end{array}$ \\
\hline
\end{tabular}

* CDM = Crepon, Duguet, Mairesse model described in text. ALS = asymptotic least squares on multi-equation model. $3 \mathrm{SLS}=$ three stage least squares. FIML = full information maximum liklihood on multivariate normal model. OLS = ordinary least squares. IV = instrumental variable estimation.

Source: Author's collection, supplemented by Tabla A.1 (Chudnovsky et al 2006), Table 4.1 (Peters 2006). 
Appendix Table 2: Empirical studies of the productivity-innovation relationship using productivity growth

\begin{tabular}{|c|c|c|c|c|c|c|c|}
\hline Authors (year) & Country & Observations & Method & Output measure & Innov measure & Estimated effect & Result \\
\hline $\begin{array}{l}\text { Belderbos, } \\
\text { Carree, \& Lokshin } \\
(2004)\end{array}$ & $\begin{array}{l}\text { Nether- } \\
\text { lands }\end{array}$ & $\begin{array}{l}\text { CIS2, CIS3 1996- } \\
1998 \\
2056 \text { mfg firms }\end{array}$ & $\begin{array}{l}\text { Productivity eq } \\
\text { only }\end{array}$ & Log VA per emp & $\begin{array}{l}\text { Innov exp per } \\
\text { sales }\end{array}$ & elasticity $0.0002(0.00003)^{* * *}$ & $\begin{array}{l}\text { productivity and innov sales share on lagged } \\
\text { innovative activity and various kinds of cooperation }\end{array}$ \\
\hline $\begin{array}{l}\text { Chudnovsky, } \\
\text { Lopez, \& Pupato } \\
\text { (2006) }\end{array}$ & Argentina & $\begin{array}{l}\text { INDEC-SECYT 1992- } \\
1996 \\
\text { INDEC-SECYT 1998- } \\
2001 \\
718 \text { mfg firms in } \\
\text { a panel }\end{array}$ & $\begin{array}{l}\text { CDM variation: } \\
\text { sequential } \\
\text { estimation with } \mathrm{FE}\end{array}$ & Log sales per emp & \begin{tabular}{|l|} 
product and \\
process dummies; \\
interactions
\end{tabular} & \begin{tabular}{|ll} 
prod only: & $0.09(0.08)$ \\
proc only: & $0.18(0.08)^{* *}$ \\
both: & $0.14(0.06)^{* *}$ \\
any: & $0.13(0.05)^{* * *}$
\end{tabular} & $\begin{array}{l}\text { uses innov expend rather than R\&D; fixed effect } \\
\text { single eq estimation. Uses logit for prod/proc/both } \\
\text { innovation dummies. R\&D increases prob of prod } \\
\text { innov; Tech acquisition increases prob of both }\end{array}$ \\
\hline $\begin{array}{l}\text { Criscuolo \& } \\
\text { Haskel (2003) }\end{array}$ & UK & $\begin{array}{l}\text { CIS2, } 3 \text { 1994-2000 } \\
5000 \mathrm{mfg} \text { firms }\end{array}$ & $\begin{array}{l}\text { single eq regression } \\
\text { for TFP growth: OLS }\end{array}$ & $\begin{array}{l}\text { TFP growth (not } \\
\text { clear if sales or VA) }\end{array}$ & $\begin{array}{l}\text { Process dummy; } \\
\text { share of innov } \\
\text { sales }\end{array}$ & $\begin{array}{l}\text { proc 94-96: } 0.016(0.009)^{*} \\
\text { proc 98-00: }-0.038(0.019)^{* *} \\
\text { prod 94-96: }-0.022(0.017) \\
\text { prod 98-00: } 0.065(0.033)^{* *}\end{array}$ & $\begin{array}{l}\text { Process innovation lead to TFP growth but with } \\
\text { substantial lag; novel process innovations negative at } \\
\text { first }\end{array}$ \\
\hline Duguet (2006) & France & $\begin{array}{l}\text { SESSI 1986-90 } \\
\sim 5000 \mathrm{mfg} \text { firms }\end{array}$ & $\begin{array}{l}\text { TFP growth reg } \\
\text { with latent innov or } \\
\text { dummies (GMM) }\end{array}$ & Log VA per hour & $\begin{array}{l}\text { dummies for } \\
\text { radical \& } \\
\text { incremental } \\
\text { innovation }\end{array}$ & $\begin{array}{l}0.022(0.004)^{* * *} \text { radical } \\
-0.01(0.01) \text { incremental }\end{array}$ & $\begin{array}{l}\text { only radical innovations affect TFP growth, with a } \\
\text { coefficient of } 0.02 \text {. latent innovation does not enter. }\end{array}$ \\
\hline Geroski (1989) & UK & $\begin{array}{l}1976-79 \\
79 \text { industries }\end{array}$ & panel reg (CRS) & $\begin{array}{l}\text { Log output per } \\
\text { capital }\end{array}$ & $\begin{array}{l}\text { \# ind innov (flow) } \\
\text { during past } 3 \text { yrs }\end{array}$ & $0.025(0.010)^{* *}$ & $\begin{array}{l}\text { distributed lag of innovation counts more important } \\
\text { than entry for TFP. }\end{array}$ \\
\hline $\begin{array}{l}\text { Huergo \& } \\
\text { Jaumandreu } \\
\text { (2004) }\end{array}$ & Spain & $\begin{array}{l}1990-98 \\
2300 \mathrm{mfg} \text { firms }\end{array}$ & $\begin{array}{l}\text { semiparametric } \\
\text { estimate of TFP }\end{array}$ & TFP growth & $\begin{array}{l}\text { process innov } \\
\text { dummy }\end{array}$ & $\begin{array}{l}0.015(0.004)^{* * *} \text { all } \\
0 \text { uncensored (innovators) }\end{array}$ & $\begin{array}{l}\text { Process innovation lead to TFP growth immediately, } \\
\text { then declines slowly over time. Primary interest is age } \\
\text { distribution of investment returns. }\end{array}$ \\
\hline $\begin{array}{l}\text { Loof \& Heshmati } \\
\text { (2006) }\end{array}$ & Sweden & $\begin{array}{l}\text { CIS3 1996-98 } \\
\sim 3000 \mathrm{mfg} \\
\text { service, + utility } \\
\text { firms }\end{array}$ & \begin{tabular}{|l} 
sensitivity analysis \\
using CDM model
\end{tabular} & Log VA per emp & $\begin{array}{l}\text { Log innov sales per } \\
\text { emp }\end{array}$ & $\begin{array}{l}0.07(0.03)^{* *} \mathrm{mfg} \\
0.08(0.03)^{* * *} \text { service }\end{array}$ & $\begin{array}{l}\text { mfg, prod level - } 0.12 \text { elasticity with innov sales } \\
\text { higher for profits, lower for services } \\
\text { mfg, prod growth - elasticity } 0.07 \text { wrt innov sales } \\
\text { higher for profits; and for services } \\
\text { survey data less reliable than register data; sales not } \\
\text { as good as VA }\end{array}$ \\
\hline $\begin{array}{l}\text { Parisi, } \\
\text { Schiantarelli, \& } \\
\text { Sembenelli } \\
\text { (2006) } \\
\end{array}$ & Italy & $\begin{array}{l}\text { MCC 1992-1997 } \\
465 \text { mfg firms } \\
\text { in both surveys }\end{array}$ & $\begin{array}{l}\text { TFP growth } \\
\text { regressions: IV }\end{array}$ & Log sales per emp & $\begin{array}{l}\text { Product and } \\
\text { process dummies }\end{array}$ & $\begin{array}{l}\text { prod: } 0.12(0.09) \\
\text { proc: } 0.04(0.12)\end{array}$ & $\begin{array}{l}\text { Process innovations add to prod growth; product } \\
\text { innovations do not enter. R\&D elasticity is } 0.04 \text {. R\&D } \\
\text { enters product innovation but not process. }\end{array}$ \\
\hline
\end{tabular}




\begin{tabular}{|c|c|c|c|c|c|c|c|}
\hline Peters (2006) & Germany & $\begin{array}{l}\text { MIP 2000-2003 } \\
522 \mathrm{mfg} \text { innov } \\
\text { firms }\end{array}$ & $\begin{array}{l}\text { CDM variation: } \\
\text { sequential } \\
\text { estimation }\end{array}$ & Log sales per emp & $\begin{array}{l}\text { Log innov sales per } \\
\text { emp; Log cost } \\
\text { reduction per emp }\end{array}$ & $\begin{array}{l}\text { prod: } 0.04(0.02)^{* *} \\
\text { proc: } 0.14(0.08)^{*}\end{array}$ & $\begin{array}{l}\text { Uses survey estimates of cost savings due to procuess } \\
\text { innovation as well as innovative sales share; lag } \\
\text { between innovation and productivity growth }\end{array}$ \\
\hline $\begin{array}{l}\text { Sterlacchini } \\
\text { (1989) }\end{array}$ & UK & $\begin{array}{l}1954-84 \\
15 \mathrm{mfg} \text { inds }\end{array}$ & $\begin{array}{l}\text { cross sections for 6- } \\
\text { year periods }\end{array}$ & $\begin{array}{l}\text { TFP growth } \\
\text { averaged over } 6 \\
\text { years }\end{array}$ & $\begin{array}{l}\text { \# ind innov } \\
\text { produced; \# ind } \\
\text { innov used }\end{array}$ & $\begin{array}{l}0.08(0.04)^{* *} \text { inn produced } \\
0.07-0.30 \text { innov used }\end{array}$ & $\begin{array}{l}\text { correlates R\&D and SPRU innovations by industy of } \\
\text { origin and use - ranking same. Prior to } 73 \text {, ind of more } \\
\text { impt for TFP. After, correlation btwn R\&D growth and } \\
\text { TFP, probably due to simultaneity. In } 80 \text { s, relationship } \\
\text { btwn R\&D/innov \& TFP breaks down }\end{array}$ \\
\hline $\begin{array}{l}\text { van Leeuwen } \\
\text { (2002) }\end{array}$ & $\begin{array}{l}\text { Nether- } \\
\text { lands }\end{array}$ & $\begin{array}{l}\text { CIS2,3 1994-1998 } \\
1929 \text { mfg innov } \\
\text { firms } \\
510 \text { mfg innov } \\
\text { firms pooled }\end{array}$ & $\begin{array}{l}\text { CDM variation: } \\
\text { FIML on submodels } \\
\text { for selection }\end{array}$ & Log sales per emp & $\begin{array}{l}\text { share of innov } \\
\text { sales; process } \\
\text { dummy }\end{array}$ & $\begin{array}{l}\text { prod dyn: } 0.006(0.004)^{*} \\
\text { prod static: } 0.009(0.001)^{* * *} \\
\text { proc dyn: }-1.2(0.7)^{*} \\
\text { proc static: }-0.20(0.50)\end{array}$ & $\begin{array}{l}\text { uses Griliches-Mairesse } 1984 \text { to connect revenue to } \\
\text { knowledge stock via demand equation; also includes } \\
\text { process innovation dummy. Estimation is both static } \\
\text { (pooled across periods) and dynamic (second period } \\
\text { only) }\end{array}$ \\
\hline
\end{tabular}

${ }^{*} \mathrm{CDM}=$ Crepon, Duguet, Mairesse model described in text. ALS = asymptotic least squares on multi-equation model. $3 S \mathrm{SLS}=$ three stage least squares. FIML = full information maximum liklihood on multivariate normal model. OLS = ordinary least squares. IV = instrumental variable estimation.

Source: Author's collection, supplemented by Tabla A.1 (Chudnovsky et al 2006), Table 4.1 (Peters 2006). 